\title{
Highways and Wildlife: Problems and Solutions ${ }^{1}$
}

Joe Schaefer, Frank J. Mazzotti, and Craig Huegel ${ }^{2}$

\section{Introduction}

The expanding network of highways built to transport Florida's residents and visitors has a severe impact on our wildlife resources. Information on this topic is currently in great demand by conservationists, planners, and road builders. Increased knowledge of wildlife movements, use of habitat, and reactions to highways, in addition to greater experience with innovative roadway designs, offer opportunities to lessen the negative impacts of roads on native fauna. This fact sheet summarizes the known or suspected relationships between highways and wildlife in Florida, and solutions that may help to minimize problems. Readers are encouraged to consult the listed references for more information.

\section{Problems}

\section{Habitat Fragmentation}

Florida's highway system covers the state like a giant spiderweb. Roads, as well as other human land uses, have fragmented the once vast, naturally connected landscape into a mosaic of various-sized islands surrounded by asphalt moats. This design forces some animals that are reluctant to cross highways to carry out life functions such as feeding, courtship, and nesting in small habitat patches.

Smaller isolated areas may accommodate only a few individuals with modest home range requirements. Somewhat larger parcels may be suitable for populations of several species of small-sized animals. Very few remaining habitat patches are large enough to provide spatial needs of far-ranging species such as the Florida Panther (Felis concolor coryi) and the Florida Black Bear (Ursus americanus floridanus). Highways also facilitate development and access to previously remote areas leading to secondary effects of habitat loss and fragmentation. The loss of only one species from a small isolated habitat may also affect other species (e.g., predator and prey species) and alter natural functions of the area.

\section{Movement and Distribution Patterns}

Many wildlife are reluctant to enter into or cross over highway rights-of-way. Black Bear, small mammals and other forest dwelling wildlife have shown an aversion to using these areas with less vegetative cover. Movements and distribution patterns of a grassland species, the endangered Florida grasshopper sparrow (Ammodramus

1. This is document WEC-172, one of a series of the Department of Wildlife Ecology and Conservation, Florida Cooperative Extension Service, Institute of Food and Agricultural Sciences, University of Florida. Published:1993, as SS-WIS-41. Revised: February, 2003. Please visit the EDIS Web site at http://edis.ifas.ufl.edu.

2. Joe Schaefer, Professor; Frank J. Mazzotti, Associate Professor; and Craig Huegel, former Urban Wildlife Extension Scientist, Wildlife Ecology and Conservation Department, University of Florida, Institute of Food and Agricultural Sciences, Gainesville, Florida, 32611. 
savannarum floridanus), also seem to be restricted by narrow, infrequently used roadways. One researcher suggests that divided highways with clearances $\geq 90$ $\mathrm{m}(270 \mathrm{ft})$ are as effective barriers to the dispersal of small forest mammals as bodies of fresh water twice as wide. Of course, strip development that occurs along roadways also increases the total width of this relatively inhospitable habitat.

\section{Mortality and Injury}

Although some animals have an aversion to highways, many attempt to navigate across them to use the food, cover, and/or water requirements on the other side. As a consequence, vehicles striking animals on highways are a major problem for wildlife and humans. During 1990, 431 vehicle collisions with animals (wild and domestic) were serious enough to be reported to the Florida Department of Highway Safety and Motor Vehicles. These accidents resulted in 4 human fatalities and 380 injuries. The average estimated property damage for each accident was $\$ 3,395$.

Highway mortality and injury statistics have not been obtained for all wildlife species. A few studies have provided data on limited sections of Florida's road system. For example, one study during the mid 1970s found a monthly average of 233 snakes (alive and dead) on a $2.9 \mathrm{~km}$ (1.8 mile) section of State Road 441 that runs through Paynes Prairie State Preserve in Alachua County. Although wildlife mortality information for some listed species is recorded by the Florida Fish and Wildlife Conservation Commission Bureau of Wildlife Research (Wooding and Brady 1987; Maehr, Land and Roelke 1991; Figure 1), very little information on the extent of this problem for all species within the state has been collected.

Vehicle speed is one factor that influences the number of collisions with wildlife. A North Florida study reported a greater number of road kills in high posted speed limit areas. Other researchers found that $76 \%$ of road kills in Virginia, North Carolina, and California during 1978-79 occurred on interstate highways. Speed alone also accounted for $85 \%$ of the variation in road kills for all species found along I-80 in Nebraska from 1969 to 1975. Another report concluded that because $68.9 \%$ of highway bird

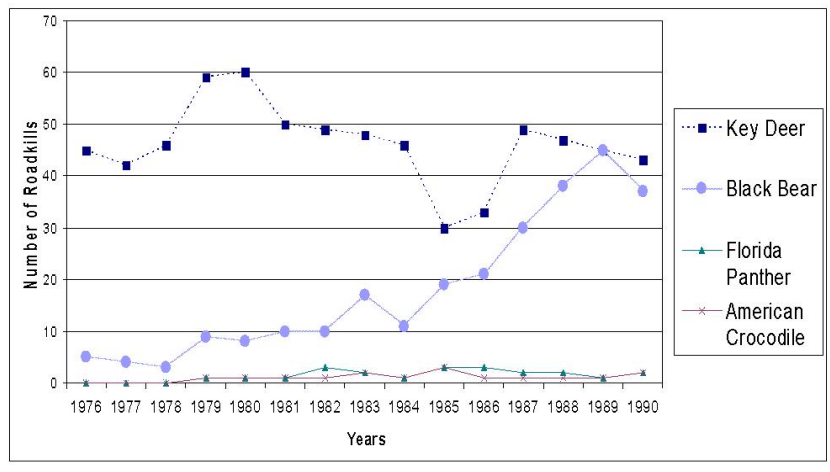

Figure 1. Panther, Key Deer, Black Bear, and Crocodile Roadkills in Florida (1975-1990). Source: Wooding and Brady 1987; Maehr, Land and Roelke 1991.

mortality on a Bulgarian highway occurred in the downhill lanes where cars were usually traveling faster than those moving uphill, vehicle speed was a major influence.

Several other factors also influence the extent of highway mortality of wildlife. Traffic volume and road surface width often have been directly related to the number of road kills. Landscaping of the highway shoulders and medians also has a bearing on how likely certain species are to be struck by a vehicle. Small and medium-sized (e.g., bobcat $\{$ Felis rufus\}) mammals are sometimes more reluctant to cross wide than narrow roadway clearances. Tall vegetation in the median gives the appearance of a narrow clearance. Consequently, higher mortality generally occurs on roadway sections with un-mowed herbaceous medians (good concealment cover) than on those with mowed medians. In Texas, cedar waxwings (Bombycilla cedrorum) attracted to fruit-producing plants in the median of a four-lane highway experienced high mortality as they traveled to and from this food source. Scavenger species such as opossums (Didelphis Virginia) and raccoons (Procyon lotor) that feed on roadkill also are susceptible to vehicle collisions.

\section{Solutions}

It is difficult to develop solutions to highway and wildlife collisions without having a better understanding of how each variable contributes to this problem. No studies have completely separated the relative importance of vehicle speed, traffic volume, roadway width, and habitat. Although 
several strategies to reduce negative impacts of highways on wildlife have been proposed and implemented, only a few have been proven successful.

\section{Reducing Speed Limits}

Reducing speed limits in areas where there is a high probability of a collision with an animal should result in decreased highway-related wildlife mortality and injury. Slower traffic speeds would provide longer reaction times for both drivers and animals. For this reason, lower speed limits have been posted in Florida panther habitat in South Florida, in Key deer (Odocoileus virginianus clavium) habitat in the Florida Keys, and in Florida's waterways to protect the West Indian manatee (Trichechus manatus).

\section{Habitat Management}

Species that are attracted to open, low-vegetation habitats such as most rights-of-way are more likely to be killed by cars and trucks than wildlife that do not use these habitats. Sometimes, carefully crafted habitat management provides desirable results. For example, habitat manipulation on causeways has lowered the percentage of highway mortality of two species that nest on bare ground, least terns (Sterna antillarum) and black skimmers (Rhynchops niger). Grasses planted immediately next to the road discourage nesting there, while fresh spoil gravel deposited farther away from the road attracts the birds. In most cases, designing management practices that will reduce vehicle collisions with animals is difficult. Also, such manipulation may involve a trade-off. For instance, although travel corridors planted with woody vegetation instead of grasses and forbs may encourage fewer deer to forage on highway shoulders, other species such as opossums and squirrels might be attracted and become vulnerable to collisions with vehicles. Woody vegetation in only some sections also may give the appearance of a relatively narrow roadway clearance and be more appealing to those mammals that are reluctant to attempt crossing in wide areas with little concealment cover.

\section{Underpasses and Fencing}

Safe travel for wildlife trying to cross highways has been provided by placing various configurations of tunnels under existing road surfaces. Typical drainage, culvert-size structures may be adequate for some small species, while more elaborate underpasses have been built for deer, black bear, and panther (Figure 2). These not only help to reduce the number of road kills, but also provide some linkages, although not ideal, between habitants that otherwise would be isolated. Underpasses are most effective if placed in line with migration or travel routes commonly used by wildlife. These areas can be identified by a relatively high number of road kills or documented crossings by wildlife.

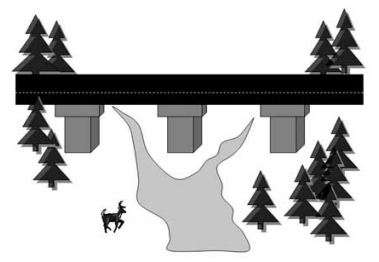

Figure 2. Highway Underpass Design for Panthers. Adapted from Figure 4 in Evink, G.L. Wildlife Crossings of Florida I-75. In Transportation Research Record 1279, Transportation Research Board, National Research Council, Washington, D.C., 1990, p.59.

Fences can enhance the effectiveness of underpasses by herding animals into these safe travel lanes under road surfaces. Fences are considered an essential component of the panther underpasses along Alligator Alley (I-75) in South Florida. Such a combination of special fences and underpasses also has been used effectively in Europe to safeguard populations of some small migrating species. These custom-designed tunnels have openings on top so rainwater keeps the tunnel wet enough for amphibians.

\section{Wildlife Crossing Signs}

Simply placing wildlife crossing signs in areas where traditional wildlife travel lanes intersect highways can alert drivers to potential encounters with animals. Although the ability of these signs to reduce vehicle collisions with animals has not been proven, they at least heighten the awareness of drivers to wildlife mortality problems. 


\section{Other Devices}

Other devices such as high frequency whistles attached to vehicles, lights, and reflectors (deer mirrors) placed along highway shoulders are being used by some states in an attempt to scare wildlife away from oncoming traffic. However, results of studies on the effectiveness of these techniques are inconclusive.

\section{Planning for Future Highways}

Highway and wildlife problems can best be addressed if wildlife considerations are included in plans for future highways. Road systems should be designed to minimize fragmentation of important habitats and to prevent isolation that might likely cause extirpation of imperiled species. Because roads facilitate strip development, potential secondary impacts on wildlife in areas adjacent to highways also should be analyzed. Once the location of a public transportation route is decided, monitoring wildlife movement patterns before construction will help determine best placement of effective structures such as underpasses (Figure 2) and fences.

\section{What You Can Do}

1.) Be on the lookout for sections of roadways that have frequent road kills and work with the appropriate transportation authority to take measures to reduce the mortality.

2.) Encourage only those development plans that minimize habitat fragmentation and maximize measures to protect wildlife. Exemplary developments would include only the minimum number of roadways required in the areas of least impact with the narrowest width needed, and designed to provide the fewest barriers to the movements of wildlife.

3.) Propose and support amendments to the transportation plan for your county or municipality that require the inclusion of fragmentation considerations, and sufficient wildlife underpasses and other wildlife and wildlife habitat conservation measures for all present and future roadways.
4.) Encourage conscientious, wildlife-conserving driving habits in your family and friends. Obeying the posted speed limit and keeping alert to avoid hitting wildlife will be in everyone's best interest.

\section{Literature Cited}

Adams, L.W., and A.D. Geis. 1981. Effects of highways on wildlife. U.S. Dept. Transportation, Federal Highway Administration. Report No. FHWA-RD-81-67. 149 pp. Available from National Technical Information Service, Springfield, VA 22161.

Adams, L.W., and A.D. Geis. 1983. Effects of roads on small mammals. Journal of Applied Ecology 20:403-415.

Adams, L.W., and A.D. Geis. 1984. Small mammal use of an interstate highway median strip. Journal of Applied Ecology 21:175-178.

Brody, A.J., and M.R. Pelton. 1989. Effects of roads on black bear movements in western North Carolina. Wildlife Society Bulletin 17:5-10.

Case, R.M. 1978. Interstate highway road-killed animals: a data source for biologists. Wildlife Society Bulletin 6:8-13.

Christopher, C. 1991. Road mortalities of northern Florida vertebrates. Florida Scientist 54:65-68.

Evink, G. 1990. Wildlife crossings of Florida I-75. In Hydrology and Environmental Design, 1990. In Hydrology and Environmental Design, 1990. Transportation Research Record, No. 1279. Transportation Research Board, Washington, D.C. Pp. 54-59.

Leedy, D.L. 1975. Highway-wildlife relationships. Vol.1. A state-of-the-art report. U.S. Dept. Transportation, Federal Highway Administration. Report No. FHWA-RD-76-4. 183 pp. Available from National Technical Information Service, Springfield, VA 22161.

Leedy, D.L., and L.W. Adams. 1982. Wildlife considerations in planning and managing highway 
corridors. Users manual. U.S. Dept. Transportation, Federal Highway Administration. Report No.

FHWA-TS-82-212. 93 pp. Available from National Technical Information Service, Springfield, VA 22161.

Maehr, D.S., E.D. Land, and M.E. Roelke, 1991. Mortality patterns of panthers in southwest Florida. Proceedings of the Annual Conference of Southeastern Fish and Wildlife Agencies 45: (in press).

Puglisi, M.J., J.S. Lindsey, and E.D. Bellis. 1974. Factors associated with highway mortality of white-tailed deer. Journal of Wildlife Management 38:799-807.

Wilkins, K.T., and D.J. Schmidly. 1980. Highway mortality of vertebrates in southeastern Texas. Texan Journal of Science 32:343-350.

Wooding, J.B. and J.R. Brady. 1987. Black bear roadkills in Florida. Proceedings of the Annual Conference of Southeastern Fish and Wildlife Agencies 41:438-442. 